AP18

Regional Stratigraphic Framework, Depositional Environments, and Exploration Concepts of the Upper Jurassic Carbonates and Evaporites, Saudi Arabia

D.Z. Tang* (Saudi Aramco), P. Lawrence (Saudi Aramco), W. Tan (Saudi Aramco), A.F. Bakhiet (Saudi Aramco), G. Gregory (Saudi Aramco), S. Wharton (Saudi Aramco) \& K. Shokair (Saudi Aramco)

For abstract, PTO

No full paper available 


\title{
15098 Regional stratigraphic framework, depositional environments, and exploration concepts of the Upper Jurassic carbonates and evaporites, Saudi Arabia
}

\author{
David Z. Tang (Saudi Aramco <david.tang@aramco.com>), Paul Lawrence (Saudi Aramco), \\ Wenbin Tan (Saudi Aramco), AbdelFattah Bakhiet (Saudi Aramco), Greg Gregory (Saudi Aramco), \\ Stanley R. Wharton (Saudi Aramco) and Khalid Shokair (Saudi Aramco)
}

The Jurassic carbonates host significant oil reserves and produce from giant and super-giant oil fields. The Upper Jurassic (Oxfordian) Hanifa Formation and Middle Jurassic (Late Callovian) Tuwaiq Mountain Formation contain world-class hydrocarbon source rocks and carbonate reservoirs. The grainy carbonates of the Arab A, B, C and D members are among the best Jurassic carbonates reservoirs. The Hith Formation evaporites (Tithonian) provide excellent regional seal of the exceptionally prolific Jurassic petroleum systems. Understanding the regional stratigraphic framework by integrating core, well-logs, and 2-D/3-D seismic interpretations is essential for unlocking the hydrocarbon exploration potential and new exploration opportunities.

The Hanifa reservoirs (skeletal/oolitic limestones and packstones) were deposited as prograding clinoforms during the highstand of the Hanifa third-order composite sequence along the margins of the Hanifa intra-shelf basin, which was inherited from the Tuwaiq Mountain intra-shelf basin. The Hanifa grainstone shoaling complexes shifted further basinward as a result of continuous carbonate growth and progradation, progressively infilling most of the accommodation space that was created after Bathonian time. The organic-rich mudstones of both the Tuwaiq Mountain and Hanifa formations were deposited in the intra-shelf basins of the Jurassic Arabian carbonate platform interior.

An Early Kimmeridgian base-level fall, as revealed from core and 3-D seismic chronostratigraphic analysis, terminated the Hanifa carbonate platform and resulted in substantial subaerial exposure of previous grainstone shoaling complexes and proximal areas. A renewed regional transgression occurred post-Hanifa time, leading to deposition of the Jubaila Formation and infilling the remaining accommodation space. Widespread deposition of packstones and grainstones of the Arab D Member represents the maximum flooding and the beginning of the Late Kimmeridgian sea-level fall, which resulted in the deposition of Arab A, B, C members, and pervasive Hith anhydrite deposits across the region, marking the turning point from a predominantly carbonate factory to an overall evaporite factory.

Gross depositional environment maps of the Upper Jurassic formations have been reconstructed by integrating core/drill cutting sedimentology, well-log electrofacies, and seismic attributes. These maps depict evolving depositional environments that span the Hanifa intra-shelf basin, Arab Formation carbonate platform, and finally the Hith evaporite system. A variety of new exploration concepts have emerged through the building of a robust stratigraphic framework and reconstruction of gross depositional environments. 